\title{
"A Superior Kind of Working Woman": The Contested Meaning of Vocational Education for Girls in Progressive Era Chicago
}

\author{
Ruby Oram* (D) \\ Texas State University, San Marcos, TX, USA \\ ${ }^{\star}$ Corresponding author. E-mail: rubyoram@txstate.edu
}

\begin{abstract}
Progressive Era school officials transformed public education in American cities by teaching male students trades like foundry, carpentry, and mechanics in classrooms outfitted like factories. Historians have demonstrated how this "vocational education movement" was championed by male administrators and business leaders anxious to train the next generation of expert tradesmen. But women also hoped vocational education could prepare female students for industrial careers. In the early twentieth century, members of the National Women's Trade Union League demanded that public schools open trade programs to female students and teach future working women the history of capitalism and the philosophy of collective bargaining. Their ambitious goals were tempered by some middleclass reformers and club women who argued vocational programs should also prepare female students for homemaking and motherhood. This article uses Chicago as a case study to explore how Progressive Era women competed and collaborated to reform vocational education for girls, and how female students responded to new school programs designed to prepare them for work both in and outside the home.
\end{abstract}

Keywords: Chicago; education; labor; school reform; women and gender

In 1914, Agnes Nestor of the Chicago Women's Trade Union League (WTUL) went to the offices of the Board of Education with a resolution in hand. Nestor, a twenty-three-yearold glovemaker and labor activist, hoped to convince school officials to offer a course on collective bargaining for students enrolled in vocational programs at Chicago public high schools. She and her colleagues argued that female students in particular needed to learn their labor rights to help women workers avoid dangerous and poorly paid positions in the industrial economy. Nestor was surprised when the city's superintendent of schools, Dr. Ella Flagg Young, agreed to a meeting. Young and Nestor did not always get along. The first woman to oversee a major school system in America, Young was more a supporter of "household arts" education and had ignored trade union women's requests

(c) The Author(s), 2021. Published by Cambridge University Press on behalf of the Society for Historians of the Gilded Age and Progressive Era (SHGAPE). This is an Open Access article, distributed under the terms of the Creative Commons Attribution-NonCommercial-NoDerivatives licence (http://creativecommons.org/licenses/by-nc-nd/4.0/), which permits non-commercial re-use, distribution, and reproduction in any medium, provided the original work is unaltered and is properly cited. The written permission of Cambridge University Press must be obtained for commercial re-use or in order to create a derivative work. 
to expand vocational programs for girls. Nestor was shocked with Young expressed enthusiasm for a collective bargaining course and agreed to bring Nestor's resolution to the Board of Education. Unfortunately, Young thought Nestor had suggested a course for girls on how to buy - a concept affiliated with the home economics movement-rather than how to bargain. "Evidently our terms were not familiar to her," Nestor later lamented, "as she had no previous familiarity with labor."

This misunderstanding between Nestor and Young reflected an important division in how leading women reformers understood the purpose of vocational education for female students in Progressive Era Chicago. Labor activists like Nestor wanted public high schools to train female students for work as skilled dressmakers and milliners so they could advance to better positions in the manufacturing sector. They argued that vocational programs should help future working women assert their rights through courses on collective bargaining, the history of labor legislation, and the evolution of capitalism. Their radical goals were curbed by middle-class reformers, club women, and school administrators like Young who argued that vocational programs should teach girls domestic skills for when they presumably exited the workforce for motherhood. Many women reformers in Chicago ultimately worked together to bring vocational classes like dressmaking, designing, and cooking into the city's public schools in the decades before World War I. Their shared assumptions about the needs of future garment workers and homemakers, however, led women like Nestor and Young to ignore the vocational field that many female students hoped to pursue: white-collar work.

Historians have demonstrated how women forged cross-class alliances to address a range of social issues in Progressive Era cities. Wealthy, white society women, middleclass social reformers, and working-class labor activists created their own "female dominion of reform" in Chicago through their involvement in urban settlement houses and women's club. Along with issues like child welfare and juvenile justice reform, Chicago women were united in their concern for young, immigrant female workers who labored in downtown factories. A quarter of Chicago women and girls over the age of sixteen were employed by 1910, 77 percent of whom were immigrants from southern and eastern Europe or their American-born daughters. Women from Russia, Italy, and Poland filled some of the lowest-paid positions in the industrial workforce as string cutters, errand runners, and machine hands in garment factories. Scholars such as Maureen Flanagan have argued that female reformers advocated for women's labor reform by supporting strikes, lobbying for protective labor laws, and forming organizations with working women like the National Women's Trade Union League. ${ }^{2}$

Scholars have devoted less attention to the role of Progressive Era women in the development of vocational programs for girls. Between 1890 and 1917, school officials in cities like Chicago established public vocational high schools and outfitted existing schoolhouses with factory equipment for classes like carpentry, foundry, engineering, and machine shop. Historians of education suggest that this "vocational education movement" was led by male school officials who hoped to better prepare working-class boys for the industrial workforce. Indeed, many Progressive Era administrators argued that a high school education would be more "practical" for the sons of immigrants if schools offered trade programs alongside a traditional college prep curriculum. Important studies of grassroots school reform by scholars like William Reese and David Hogan have highlighted how class and ethnic tensions between parents, labor activists, and school officials impacted the development of vocational programs from the outside in. Studies of grassroots school reform have yet to fully explore how and why women reformers shaped the vocational curriculum by introducing new work-oriented programs for girls in the decades before World War I. ${ }^{3}$ 
This article uses Chicago as a case study to demonstrate how Progressive Era women reformers embraced vocational school reform to support their broader goal of increasing public investment in female workers and caretakers. Working-class reformers in the Chicago WTUL and their allies, like Jane Addams, argued that the city should establish public vocational schools run by women to train girls for skilled positions as dressmakers, milliners, and designers. These reformers intended such programs to cater primarily to foreign-born high schoolers and the American-born children of immigrants, who accounted for 88 percent of Chicago students in $1906 .{ }^{4}$ Philanthropic women in the Chicago Woman's Club (CWC) argued that immigrant female workers would have cleaner homes and healthier children when they exited the workforce if vocational programs for girls also included domestic skills like cooking and housekeeping. Women reformers were united in their strong conviction that public vocational schools for girls could have a profound impact on the future working lives of Chicago women. Their conflicting views on the degree to which domestic education should be included, however, reveal where branches of their reform community splintered on the question of women's work outside the home. ${ }^{5}$

Women school reformers in Chicago compromised on a limited set of vocational programs for girls before World War I that did not align with the work goals of many female students. Chicago labor activists, middle-class reformers, and wealthy club women agreed that programs like sewing and dressmaking could help girls find better positions in the garment trades as well as provide better care for their future children. Yet oral histories and enrollment data reveal that Chicago's female students largely ignored these programs and pursued vocational programs for white-collar employment instead. Immigrant daughters in particular crowded into "commercial" classes such as stenography and bookkeeping and were uninterested in programs designed by women like dressmaking and cooking. Women's reform groups in Chicago promoted a narrow vision of vocational education for girls due to their shared assumption that immigrant female students would primarily find work in shops and factories. Chicago's female students proved otherwise by foregoing domestic-oriented lessons in pursuit of economic advancement.

\section{"The School of the Future"}

In 1907, Jane Addams, the eminent reformer and cofounder of Chicago's Hull-House settlement, argued that American public schools failed to prepare male and female students for life in an industrial society. Public school teachers were trapped in "the caves of classic learning," she wrote, and neglected the modern skills and knowledge needed for safe and productive careers in industry. Addams suggested that public education could become obsolete if school officials did not expand curricula to include vocational programs and new subjects like the history of American manufacturing. "To separate educational interests from contemporary life," she warned, would mean "that education grows meaningless." 6

Addams published these words of caution in the inaugural bulletin of the National Society for the Promotion of Industrial Education (NSPIE), which was founded in 1906 by a group of influential male educators, social scientists, and businessmen who lobbied for the integration of vocational programs in American high schools. ${ }^{7}$ Of particular concern to the NSPIE was that the United States would fall behind its industrial competitors, particularly Germany, if more educational resources were not devoted to training highly skilled workers. In a 1908 study, the society reported that 55 percent of male students in 
Berlin between the ages of fourteen and sixteen were enrolled in trade programs to become "real craftsmen." But in the manufacturing center of Chicago, according to their findings, less than 1 percent of male students received dedicated trade training. "In the long run," an NSPIE representative asserted, "American industry will pay the penalty of this unpreparedness." Even President Theodore Roosevelt supported the NSPIE's mission, arguing in 1908 that vocational training was "vital to our future progress" to compete "for the markets of the world." 8

The NSPIE celebrated Edwin G. Cooley, Chicago's superintendent of schools from 1900 to 1909, for establishing a system of German-inspired vocational education in the city's public high schools. Cooley was a former blacksmith turned progressive pedagogue who agreed that urban high schools should invest more resources in preparing students to support the nation's manufacturing sector. Cooley argued that public high schools in most American cities privileged "the professional classes" by preparing students for college and commercial careers. He believed that subjects like Latin, geography, typing, and accounting were impractical for the majority of Chicago students who came from working-class and immigrant backgrounds. "It has taken us a long time to wake up to the fact that we should also help the mechanic, the clerk, and the farmer," Cooley wrote in 1908. "They make up the body of our citizenship and they have been discriminated against."

Under Cooley's leadership the Board of Education equipped nearly half of Chicago's public high schools with factory-style workrooms for boys to learn carpentry, foundry, machine shop, pipefitting, construction drawing, and electric shop. Chicago school officials also established two state-of-the-art high schools dedicated to the industrial training of high school boys: the Richard Crane Technical High School for Boys (established in 1903) and the Albert Lane Technical High School for Boys (established in 1909). ${ }^{10}$ Both schools were outfitted with expensive shop-room machinery for lessons on foundry, woodturning, electric construction, carpentry, bookbinding, and mechanical drawing. Lane Tech, built to accommodate 2,500 male students, included adjoining lecture rooms to each shop room where pupils received instruction in technique and method. Chicago's technical high schools also offered a standard high school curriculum but did not include classes for white-collar work like typing or accounting. Cooley argued that vocational education should focus on industrial labor rather than clerical jobs. "The school of the future," he announced in 1909, "will in all grades be largely industrial."11

Addams argued that Cooley's "schools of the future" should address the wage-earning needs of female students as well. Addams was appointed to the Chicago Board of Education in 1905 and worked to convince her fellow board members to fund vocational schools for girls similar to Lane Tech and Crane Tech for boys. Unsuccessful in the endeavor, Addams joined the NSPIE the following year to promote vocational education for girls in the society's national lobbying efforts. Addams and fellow social reformer Mary Morton Kehew of Boston were the only women who served on the NSPIE's Board of Managers. In 1907, they organized an NSPIE women's subcommittee to investigate the vocational needs of female students in American cities. Addams and Kehew argued that the NSPIE should not ignore the growing percentage of female students who left urban public schools to support the nation's industrial economy. In a 1908 report, they asserted that a female worker under the age of twenty without vocational training made an average of $\$ 6$ to $\$ 8$ per week as a factory hand, whereas women and girls who learned a trade like dressmaking or millinery made an average of $\$ 15$ to $\$ 20$ per week. Addams and Kehew concluded that female students also required training "for the industrial civilization in which they are to live" if the United States hoped "to maintain her rank as a great industrial Nation."12 
Addams and Kehew were both longtime labor supporters and helped to organize the National Women's Trade Union League in 1903. The National WTUL was a cross-class coalition of women dedicated to organizing female workers in labor unions, spreading awareness of women's working conditions, and advocating for protective labor legislation. Local WTUL chapters were often governed by college-educated reformers like Addams and Kehew and represented by a rank and file of trade union women. WTUL members argued that a lack of union representation further marginalized working women by limiting their access to vocational training and apprenticeships. The National WTUL's constitution declared its commitment to public vocational schools that could help women and girls "increase their economic value" through learning skilled trades like dressmaking. By the 1910s, the National WTUL encouraged its members to pursue seats on local school boards in order to oversee "exactly what education the girls are getting." One of the WTUL's most active chapters was in Chicago, where Addams helped to build strong ties between her fellow middle-class reformers and the labor community. ${ }^{13}$

Chicago school officials resisted the requests of Addams and local WTUL members to create vocational programs for future wage-earning women. Seven out of ten high school students in Chicago were female in 1900, most of whom used their high school educations as a stepping-stone to gain teaching certification. Many male school officials viewed trade programs for boys as a solution to correct the gender imbalance in Chicago's high schools by appealing to boys' "natural" proclivity for physical exertion. As one Chicago administrator asserted, boys were "more restless than girls" in school due to their innate desire for independence and selfsufficiency. Hands-on vocational programs for boys, Cooley wrote in 1902, were important to ensure that Chicago's high schools did not become "girls' schools." ${ }^{4}$

School officials in other American cities also established vocational schools to increase male enrollment. Some public vocational schools for boys in East Coast cities like Boston and Philadelphia emphasized vocational training of future managers and business leaders by expanding business programs and commercial programs. Cooley and his colleagues argued that these East Coast high schools made boys "lamblike," whereas Chicago's technical schools turned boys into skilled tradesmen. In 1908, the principal of Lane Tech argued that Boston boys lacked "the strength and virility and rough and ready manners of our Chicago youth" due to the city's focus on white-collar coursework. After spending a day among Boston's male students who were "so good that they would not even whisper," he longed for "the brain and brawn of our red-corpuscled Chicago boys."15

Addams and her colleagues in the Chicago WTUL hoped that integrating vocational programs in urban high schools would do more than churn out rugged workers. One of the WTUL's most vocal advocates of vocational education in public schools was Agnes Nestor, the American-born daughter of Irish immigrants who helped organize the International Glove Workers Union in 1903. Nestor argued that Chicago's boys-only technical schools should welcome female students and offer additional programs for girls like dressmaking, printing, and garment design. During an American Federation of Labor (AFL) convention in 1909, Nestor suggested that public vocational schools teach students the history of capitalism and the philosophy of collective bargaining. She also contended that school officials should require students to study local labor laws before leaving school for positions in shops and factories. In sum, Nestor suggested that vocational education for both male and female students should teach students the values of and rights secured by the labor movement in addition to trade skills. ${ }^{16}$

Leading WTUL members like Nestor believed that an education in labor values and labor rights could help female students better protect themselves from industrial oppression. Margaret Dreier Robins, a wealthy social reformer and president of the Chicago 
WTUL from 1907 to 1914, argued that women would remain on the lowest rungs of the garment industry if vocational programs only taught female students sewing skills. She asserted that a vocational program for future dressmakers should include the study of current labor laws, textile production methods, and the skills necessary to supervise a shop room. At an NSPIE conference in 1910, Robins described this as the difference between teaching a girl to labor and teaching a girl "the value of her labor power." Rose Schneiderman, a New York hat-stitcher and union organizer, put it a different way: "The Women's Trade Union League is not interested merely in making more efficient machines out of our people," she wrote of vocational education in 1914. "We want to make better human beings." 17

Women affiliated with the WTUL thus promoted a radically different vision of vocationalism than other leaders in the American vocational education movement before World War I. According to its constitution, the NSPIE was founded to ensure that American students became more "effective economic units." 18 The WTUL, in contrast, hoped that vocational education would make students more effective members of the labor movement and help female workers in particular secure safer and better-paid positions. These goals for vocational school reform also differed from those of male labor leaders, many of whom were initially suspicious of the vocational education movement for fear that public schools would train strikebreakers or destabilize the union apprenticeship tradition. Early financial support for vocational schools came from wealthy business leaders in cities like Chicago, which deepened antipathy among male trade unions. The AFL eventually joined the NSPIE in 1910 to work with rather than against education reformers on vocational programming in urban public schools. The WTUL supported vocational education sooner because women union leaders like Nestor had virtually no power to threaten. Instead, these women hoped to forge alliances with school officials as early as 1903 and to use vocational training to support future garment workers' economic advancement. ${ }^{19}$

\section{"We, Too, Loved the Home"}

WTUL members had reason to believe that they could successfully reform vocational opportunities for female students in Chicago public schools. City schools in the early twentieth century were increasingly staffed by prominent Chicago women who supported or were affiliated with urban reform groups. Members of the Chicago Woman's Club (CWC), the city's most influential women's club, won seats on the Board of Education in the 1890s, for example, and famed educator Margaret Haley organized the Chicago Teachers Federation (CTF) to improve working conditions for female teachers in 1897. Indeed, public schools were already considered sites of reform for Progressive Era women's groups in Chicago when vocational programs for boys entered the curriculum. ${ }^{20}$

CWC members were the first to lobby school officials to open a public vocational school for female students. Founded in 1876, the CWC was led by reform-minded society women - the wives of bankers and business leaders-who used their financial resources and political connections to address issues like education, child welfare, and juvenile justice reform. The CWC submitted multiple resolutions to the Chicago Board of Education between 1906 and 1909 demanding that school officials invest in at least two public vocational schools for girls similar to Lane Tech and Crane Tech for boys. The CWC also asked that school officials introduce an "industrial arts" program for girls into the city's fifteen other public high schools, most of which already offered trade programs 
for boys like machine shop and drafting. By 1909, the resolution was endorsed by dozens of other women's clubs representing some 20,000 members across the state of Illinois. ${ }^{21}$

Club women affiliated with the CWC hoped that Chicago's technical schools for girls would look similar to two pioneering East Coast institutions, the Boston Trade School for Girls (established in 1902) and the Manhattan Trade School for Girls (established in 1904). Both were founded and financially supported by women's groups until absorbed by their respective public school systems in 1908. The trade schools prepared female students between the ages of fourteen and seventeen for work in the female-dominated garment and artistic trades. Students at the Manhattan Trade School learned to make swimsuits, shirts, aprons, and dresses in factory-style workrooms outfitted with rows of footpowered sewing machines. The Boston Trade School had a program for girls to learn "fancy work" skills like embroidery and lace, which they used to make garments, gloves, and lampshades. Many of these programs were taught by experienced tradeswomen in New York and Boston, some of whom were local WTUL members. ${ }^{22}$

The public trade schools in Boston and Manhattan also required students to enroll in "domestic science" classes that included cooking, meal serving, home sewing and mending, sanitation, and personal hygiene. One of the founders of the Boston Trade School, social reformer Florence Marshall, argued that domestic education ensured that working girls were prepared to run their homes when they exited the workforce for marriage. Less than a quarter of working women in America were married before World War I and the average working women only earned wages for five to seven years. In a 1909 article, Marshall reasoned that young girls should receive vocational training for both phases of work life in order to excel to a "better class of industry" as well as understand "intelligent care of the home." According to Marshall, domestic training also improved a working woman's character development, making her "more responsible, more reliable, and more womanly," and thus better positioned to find a suitable husband. ${ }^{23}$

The curricula of both trade schools were shaped by the burgeoning home economics movement. The director of the Manhattan Trade School for Girls, Mary Schenck Woolman, was an active member of the American Home Economics Association, which sought to professionalize the work of women in the home through educational programs in secondary schools and colleges. Supporters of home economics education in the early twentieth century believed that the forces of urbanization and industrialism made women's work in the home more difficult and even more dangerous, thus requiring rigorous training for the safety of families. For example, Woolman required that Manhattan Trade School for Girls students learn how to prepare meals for "strong, healthy bodies" along with the science behind sanitizing kitchen counters. ${ }^{24}$

Many women in Chicago's reform community agreed that the city's proposed vocational schools for girls should address women's work both in and outside the home. Social reformer Sophonisba Breckinridge endorsed the CWC's proposal for girls-only technical high schools in 1906. She argued that vocational programs for her working-class "sisters" should emphasize garment trades like dressmaking and millinery because girls could later use those same skills in their own homes. "Being girls, they expect to marry," she explained to the Chicago Tribune in 1906. "The working girl does not assume that she will work, always. She hasn't the professional point of view. ... It would hardly be natural to expect her to." Middle-class reformers like Breckenridge believed that vocational programs needed to address women's socially essential work as caretakers and homemakers in addition to their wage-earning potential. This viewpoint aligned with the larger reform goals of Breckenridge and her colleagues in the settlement house movement who wanted city officials to make greater investments in mothers, children, and homes. ${ }^{25}$ 
Labor women were often critical of reformers who hoped to integrate domestic education into girls' vocational schools and training programs. Some WTUL members who oversaw apprenticeships at the trade schools in Boston and New York resented school administrators' statements that cooking and cleaning classes would lead to safer homes and healthier children. Leonora O'Reilly was a thirty-four-year-old seamstress and member of the WTUL who taught shirt-making at the Manhattan Trade School for Girls. In 1914, O'Reilly was asked whether training for motherhood should be considered "vocational education" for girls. She asserted that vocational programs should only focus on skills and knowledge that would help girls earn wages. If women earned higher wages and worked fewer hours, she reasoned, more women would have the time and physical strength to cultivate fulfilling lives outside of work, and that would make workers better mothers. "I do not think that 70 per cent of children die because the mother does not know how to take care of them," O'Reilly reasoned, offering another explanation: “The mother may have been so overworked in the factory or mill that she never should have brought a child into the world." 26

Chicago WTUL members shared reservations about including domestic education in the proposed vocational public schools for girls. At an NSPIE conference in 1909, Margaret Drier Robins criticized some women reformers' desire to train girls for their "double part" as homemaker and wage-earner, which she said had led to "a great deal of confusion" over the purpose of vocational schools for female students. "I am not saying that cooking and sewing are not necessary," Robins explained to NSPIE members in Milwaukee. "But when we cheat a girl out of the training she ought to have for her breadwinning capacity ... then we make a great and grave mistake." 27

The Chicago WTUL supported the CWC's proposal for girls' technical schools in spite of the inclusion of domestic training. In her 1954 autobiography, Agnes Nestor recalled her concern at making this compromise with advocates of domestic education. She worried that including cooking and cleaning in girls' vocational education would make it "too easy to push all the girls into that field" and neglect a more pressing need to help girls find safe and stable employment. "We, too, loved the home," Nestor explained, "but the girls needed training to earn a living." Nonetheless, Nestor endorsed the CWC proposal on behalf of the International Glove Workers Union in 1906 along with other trade union representatives affiliated with the Chicago WTUL. ${ }^{28}$

Debate over the value of domestic training in vocational education for girls stemmed from the disparate class contexts of Chicago's women reformers. Trade unionists and their allies in the WTUL argued that working-class women and girls faced their greatest vocational obstacles in factories, shops, and packinghouses. Many middle-class reformers and club women suggested that the burdens of housekeeping and caregiving in the home posed more serious challenges to the future work responsibilities of female students. Progressive Era labor activists ultimately agreed on a broader vision of vocational education that addressed women's work in and outside the home, both paid and unpaid. But these women reformers were justified in their concern that such a compromise would have consequences in the years that followed.

\section{"The Champion of Girl Pupils"}

Members of the Chicago WTUL and the CWC celebrated the appointment of Dr. Ella Flagg Young as superintendent of schools after Edwin G. Cooley's retirement in 1909. Young was not only the first female superintendent of a major school system; she also 
became arguably the most politically powerful woman in America at the helm of the nation's second-largest school system. Assuming her position at the age of sixty-four, Young had devoted a long career to school reform in Chicago and had received a doctorate degree working with the famed intellectual and educational reformer John Dewey at the University of Chicago. She was deemed "the champion of girl pupils" by the press after vowing to privilege the needs of female students in the high school curriculum. "I have heard nothing but boy, boy, boy," she announced at a press conference after her appointment. "I think it is about time I heard something about girl, girl, girl." 29

Yet Young worried that girls-only vocational schools would not provide female students with adequate social skills and character development. Young viewed genderspecific public schools of any kind as an affront to the American tradition of coeducation, which she and like-minded progressive educators considered symbolic of the nation's commitment to democracy. Young argued during her first year as superintendent that single-sex vocational schools could encourage "snobbishness" among students by segregating children "who intend to earn a living" from those "supported by their families." She also suggested that female students would forego essential opportunities to learn social skills needed for courtship and marriage in all-girl programs. Writing in 1902, Young argued that public schools had a responsibility to develop the "moral character of men and women" by teaching students proper "conduct and behavior." For these reasons, Young wanted Chicago's high schools to provide a "comprehensive education" that combined vocational training, academic instruction, and character development opportunities for all students under one roof. ${ }^{30}$

Addams invited Young to a meeting of women's groups at Hull-House in 1908 in an attempt to change her position. Young had criticized Addams after she spoke on the city's need for at least one dedicated vocational school for girls. "I don't agree with Miss Addams on separate high schools for boys and girls," Young explained. "I am a decided coeducationist ... boys and girls are educated better together." Young argued that students gained important social skills in coeducational environments due to girls' civilizing effect on their male classmates. Students who wanted to become dressmakers, Young suggested, should do so on their own time. "We do not need industrial training for girls," she concluded. ${ }^{31}$

"I am not such a poor coeducationist," Addams quipped after Young's remarks, and suggested that Young's commitment to coeducation was impractical given the imbalance of vocational programs in Chicago public schools. Ideally, Addams explained, "we could add large wings for girls to Lane and Crane" and thus create coeducation in the city's current technical high schools. But doing so would be difficult, as would finding "the right men to take charge of such a school." The better option, she believed, was to create new vocational schools for girls, run by women who understood the specific needs and challenges facing female wage-earners. ${ }^{32}$

Unmoved, Young introduced nearly a dozen two-year vocational programs into the existing curriculum to make Chicago's public high schools more "comprehensive" when she became superintendent. Vocational programs were offered during the first two years in an attempt to reach students who left school and joined the workforce by age sixteen. By 1911, Chicago high school students could enroll in two-year programs for mechanical drawing, electric work, carpentry, machine shop, household arts, accounting, and stenography alongside their academic studies. However, the latter two "commercial" subjects-accounting and stenography-were the only coeducational programs. As during Cooley's tenure, the majority of the new vocational programs catered to boys; the new "household arts" program offered the only vocational training specifically designed for female students. Young argued that household arts was a comprehensive program that 
taught female students trade skills like dressmaking, homemaking duties like meal planning, and important character traits like hard work and good hygiene. ${ }^{33}$

While supportive of domestic education for girls, prominent members of the CWC criticized the household arts programs for offering little practical training for the workforce. Young assured her critics that girls who completed the two-year household arts program as part of their high school education were prepared to find good jobs in "the textile trades" as well as for the work of "efficient homemakers." In practice, however, Chicago's household arts programs mostly emphasized the latter. Young oversaw the construction of "cooking laboratories" in Chicago high schools, where girls learned the science of baking and sanitation. Many cooking labs had adjoining classrooms filled with dining room furniture assembled by male carpentry students, with which girls practiced serving meals and setting places. Sewing classes in most high schools emphasized homemaking skills like mending children's clothing and curtains rather than garment construction or designing. ${ }^{34}$

Young faced mounting pressure from women's groups to open a public vocational school for girls during the winter of 1910 and 1911. Outrage over oppressive labor conditions had prompted monthslong demonstrations of garment workers on the streets of Chicago, many of whom were young women and girls from eastern and southern Europe. Along with the Chicago WTUL, middle- and upper-class women supported the protests by bailing picketers out of jail, testifying on their behalf in court, and collecting donations to make up for lost wages. Ellen Martin Henrotin, the well-known philanthropist and CWC reformer, suggested that club women establish their own "national trade school for girls" in Chicago for skilled dressmakers during the garment workers' strike. In January of 1911, Henrotin tried unsuccessfully to open a girls' trade school in Chicago with the remaining revenue earned from the Woman's Building of the 1893 World's Columbian Exposition. ${ }^{35}$

Young agreed to address what she called the "long felt want" for a girls' vocational school less than two months after the garment workers' strike ended. Young asked the Board of Education to renovate a vacant schoolhouse in the south Loop into a vocational high school for girls. In her report to the board, she argued that it was "the duty of the City" to help protect young female workers from flooding "the most poorly paid parts" of the industrial workforce. Young also conceded that girls should receive vocational training in a dedicated facility run by women, even though "co-education is preferable in ethical practice." She suggested that the Board of Education name the school after Lucy Flower, the child welfare activist and former president of the CWC. The Lucy Flower Technical High School for Girls-popularly known as Flower Tech-opened in the fall of 1911 as Chicago's first and only public school for girls. ${ }^{36}$

To the relief of many reformist women, the vocational curriculum at Flower Tech focused on dressmaking, millinery, and designing. The school was outfitted with factorystyle classrooms filled with foot-powered sewing and buttonhole machines where girls learned various techniques for working with garments and gloves. Flower Tech's designing department featured a display room where girls practiced dressing department store mannequins. Flower Tech employed the first vocational guidance counselor in the Chicago public schools, Anne Davis, who helped students find jobs after at least two years at the school. Davis was a graduate of the University of Chicago's School of Civics and Philanthropy who often arranged for students to work in dressmaking shops or downtown department stores. Flower Tech also had an on-site laundry department in the school's basement, a dining room, and a cooking laboratory for required domestic coursework. ${ }^{37}$ 
The CWC commended Young's achievement in convincing the Board of Education to invest in the wage-earning potential of future garment-makers, designers, and saleswomen. Yet members of the Chicago WTUL resented their lack of involvement in developing the vocational programs at Flower Tech. Male union leaders had established relationships with school officials by 1912 to oversee apprenticeship programs for boys enrolled in the city's technical high schools. The International Brotherhood of Electrical Workers, among others, had seats on an advisory committee with the school board that oversaw some 600 high school apprentices each year. Tradeswomen in the WTUL hoped that Young would similarly engage "women of experience" in the training of future dressmakers at Flower Tech and allow garment unions to organize apprenticeship programs through the school. Instead, most programs were led by teachers trained in household arts education at the Chicago Normal School. ${ }^{38}$

Young's hiring choices reflected her different set of priorities in expanding vocational education for female students. Responding to critics of the school in 1912, Young argued that apprenticeship programs run by labor women would overemphasize "the money side" of vocational education and distract students from "the joy of working." She explained that Flower Tech students constructed dresses and made hats to learn "the most valuable asset in the world: initiative." Ultimately, Young suggested that the goal of girls' vocational education was character development; she hoped that students graduated with "the right attitude" toward work that they would bring to their jobs and eventually into their homes. Flower Tech's founding principal and the co-architect of the curriculum, Dora Wells, agreed that it was this emphasis on values and character that made Flower Tech graduates "a superior kind of working woman."39

Character development was central to educators like Young and Wells who assumed that working girls needed to learn social skills for their careers in marriage and motherhood. Writing in the Journal of Education, Wells argued that dressmaking students learned "dignity, self-control and willingness to take responsibility," which were important character traits for homemakers. Wells suggested that education in good behavior was particularly important for working-class and immigrant daughters who presumably did not receive such training from their own mothers at home. She admitted that Flower Tech students lost "wage-earning power" due to the school's emphasis on preparing girls for motherhood. Because the average American women spent more years in the home than in the workforce, Wells reasoned, such a loss "must be accepted as inevitable under the present organization of society." 40

Lucy Flower Technical High School for Girls was the result of successful activism by Chicago women's groups who argued that public school officials should invest in the future work lives of their female students. Yet the goals of trade unionists, middle-class reformers, and club women were only partially reflected in the Flower Tech curriculum. Programs designed by administrators like Young and Wells emphasized feminine social roles in the home, which limited student access to trade training, as reformers like Agnes Nestor had feared. Other Chicago women hoped that classes like cooking and sanitation would supplement but not replace training for wage-earning so that girls were prepared for both. Throughout her tenure as superintendent, however, Young maintained her position that women's skills in the home were of paramount importance to girls' vocational training. ${ }^{41}$

Women's groups in Chicago founded their own vocational schools for female students as a result. With financial support from the CWC, Jane Addams opened the Hull-House Trade School for Girls in 1912. The school offered dressmaking education and apprenticeship opportunities for girls over the age of fourteen who graduated from the city's elementary 
schools. Two years later, Agnes Nestor and Margaret Dreier Robins opened a school for garment workers in the Chicago WTUL's headquarters building. The Training School for Active Women Workers was the first full-time labor school in the United States and catered exclusively to young women and girls over the age of fourteen. Students studied existing labor legislation, the history of the women's movement, and the history of capitalism in courses led by WTUL members. Students had the opportunity to apprentice with skilled dressmakers and glove-stitchers and engaged in "field work" by visiting union offices and participating in strikes. Although short-lived, these programs reveal the alternative visions of vocational education for girls championed by Chicago's women reformers. ${ }^{42}$

\section{"To Learn as Much as We Could"}

Women who advocated for girls' vocational schooling rarely if ever considered what actual students desired from a work-oriented education. When Flower Tech opened in 1911, students eager to prepare for employment transferred from their neighborhood high schools across the city. Flower Tech was an open-enrollment school that welcomed any female high school-aged student regardless of her neighborhood boundary. As such, the student body included white girls from South Side enclaves like Bridgeport and Englewood; Bohemian immigrants from the west side; and a minority of African American students living in the strictly segregated "Black Belt" of Chicago. Decades after graduating, one former student recalled that Flower Tech had a reputation as a school for career-seeking "dreamers" who hoped to run their own bridal shops or become designers. Another alumna described Flower Tech as a school for "girls of a different type of personality" who wanted to work with their hands rather than read and write. The majority of students were first-generation immigrants who expected to earn wages after two or three years of high school attendance. ${ }^{43}$

Many students were disappointed with the limited vocational programs offered at Flower Tech. One student who transferred from her neighborhood high school thought she would have access to diverse trade programs like her two brothers who attended Lane Tech. As an adult, she recalled her frustration with Flower Tech's required cooking and sewing classes, lamenting that household arts "was the last thing I wanted to major in!" Students were confused with the emphasis on hat-making and designing at Flower Tech, which did not reflect the realities of the female labor market. Millinery was a shrinking industry that employed less than 2 percent of Chicago women by World War I. Some students-mostly native-born and white-found work in hat shops and department stores with help from the school's vocational guidance counselor, but immigrant and African American students were not so fortunate. One student in the millinery program recalled that no downtown hat shop would hire a Black saleswoman in spite of her rare training; she worked in a lampshade factory after graduation along with her sister, a fellow Flower Tech alumna. ${ }^{44}$

Female students were generally disinterested in the household arts programs offered at Chicago's neighborhood high schools as well. During the 1912-13 school year, less than 3 percent of female high school students in Chicago enrolled in household arts. Household arts classes were so unpopular that at least one Chicago high school discontinued the two-year program entirely by 1914 due to low enrollment. Middle-class parents often discouraged their daughters from enrolling in household arts programs in Chicago because they preferred girls to learn domestic skills at home from their own mothers. Before World War I, immigrant and African American families also resisted the household arts programs because they associated cooking and cleaning skills with the drudgery 
of domestic service. Unlike many East Coast school systems, Young decided to call Chicago's program "household arts" so that parents would not confuse the term "domestic science" with "domestic service." 45

Members of women's reform groups in Chicago rarely discussed the most popular vocational programs among female high school students: stenography and accounting. Typing and accounting classes were first introduced in Chicago high schools during the 1890s to appeal to middle-class male students bound for professional careers. As one Chicago school official explained, these programs were intended for future "captains of commerce" who would help the United States win "the global struggle for commercial supremacy." Yet white-collar programs were increasingly filled with female students in the early twentieth century, the majority of whom were daughters of recent immigrants from southern and eastern Europe. Historian Susan Strom has noted that immigrant parents were more likely to recommend clerical work for their American-born daughters than any other field of employment due to the higher wages, safer working conditions, and respectability of middle-class office culture. In 1913, one-third of all female students in Chicago public high schools were enrolled in stenography or accounting classes. ${ }^{46}$

Evening classes in stenography and accounting were also popular among high schoolaged girls who earned wages during the day. In the 1913-14 school year, over 5,000 working women and girls attended high school evening classes in Chicago. Most were under the age of twenty-one and the American-born daughters of German, Irish, and Russian immigrants. A fifteen-year-old working girl explained that she enrolled in evening bookkeeping classes at her local high school because she wanted to work in a downtown office. "It was hard giving up three evenings a week after working hard all day, but it was well worth it," she wrote in a letter to the Chicago Tribune. "The majority of us, I think, would be willing to exert ourselves a little to learn as much as we could." 47

These female students were more in tune with the future of the female economy than women reformers who emphasized garment work for girls. The expanding corporate sector and mechanization of office work had created new opportunities for women in offices at the turn of the twentieth century. Yet unlike garment work, clerical jobs were still dominated by men before World War I. Less than 10 percent of office workers in Chicago were female in 1912. Even so, girls represented 47 percent of stenography students and 30 percent of bookkeeping students in Chicago public schools that year. These numbers suggest that the clerical sector did not simply open to female workers in the early twentieth century, but that female students also pushed their way in. By 1920, a full third of working women and girls in Chicago held office positions. Many of these female workers were former Chicago public school students who learned skills like typing and bookkeeping in their neighborhood high schools. ${ }^{48}$

Members of both the Chicago WTUL and the CWC ignored commercial programs popular among female students because white-collar training conflicted with the ultimate reform agendas of Chicago women's groups. Many middle- and upper-class reformers wanted vocational programs to address women's socially essential work as caretakers and homemakers in addition to their wage-earning potential. Garment work-not office work-provided the most obvious transferrable skills between the home and workplace. Chicago WTUL members also neglected the potential economic benefits of a white-collar education because their organization was focused on empowering blue-collar women. In other words, women like Nestor wanted to improve labor conditions for working-class women rather than pull women out of the working class. Together, these reformers overlooked the vocational goal of a new generation of working women who would go on to populate Chicago's downtown offices-upward class mobility. 


\section{Conclusion}

In 1914, President Woodrow Wilson formed a commission to draft a bill that would provide federal funding to vocational programs throughout American public schools. Agnes Nestor was one of two women appointed to the commission and the only member with a working-class background. Nestor played an offensive role in thwarting the attempts of two outside women's groups-the American Home Economics Association and the General Federation of Women's Clubs-whose members lobbied for the inclusion of home economics in the bill. The resulting legislation, the Smith-Hughes Act of 1917, reflected a familiar compromise between women on the place of domestic training in the vocational education of female students. The Smith-Hughes Act allowed school officials to apply up to 20 percent of their budgets for trades and industry education toward home economics classes for girls. Funds provided through the Smith-Hughes Act supported home economics education in American high schools through the 1960s and solidified domestic training as part of girls' vocational education for the better part of the twentieth century. ${ }^{49}$

Progressive Era women in Chicago helped lay the groundwork for this expansion of home economics education. Influential reformers and club women promoted vocational programs for girls that focused narrowly on garment work and homemaking skills. These women did not intend to promote "the cult of separate spheres" in the high school curriculum. Rather, they wanted school officials to invest in the future working lives of female students through educational programs addressing women's roles as both wageearners and caretakers. Trade union women were right to worry that these hybrid programs would blur the boundaries between homemaking and wage-earning skills and make it difficult for some school officials and students to articulate the difference. Indeed, students in the 1920s recalled that Flower Tech felt more like a "finishing school" for future homemakers than a vocational school for tradeswomen. ${ }^{50}$

Women's groups in Chicago successfully argued that school officials had a public responsibility to invest in the vocational education of female students before World War I. Members of the Chicago WTUL and the CWC brought new vocational programs into public schools specifically designed for the immigrant and working-class female students who crowded urban classrooms. While many disagreed on the place of domestic education, these reformers shared cultural assumptions about young women workers that ultimately reinforced gender inequalities in the school curriculum. Household arts programs, for example, advanced the presumption that all female students would exit the workforce for motherhood and that immigrant daughters required a particular education to make that transition. This strict advocacy of trade programs for girls supported the premise of the larger vocational education movement that working-class students should prepare for working-class jobs. Attention to student enrollment and course preferences reveals that girls were not passive recipients of some women's narrow vision for their vocational futures. Instead, students made independent choices about their courses of study that impacted classrooms and future workplaces alike.

This history of conflict and compromise in vocational programs for girls underscores the importance of school reform to the broader social reform agendas of Progressive Era women's groups. Chicago women shared high hopes that vocational education could improve the lives of women and girls who labored both in factories and in their own homes. Members of the Chicago WTUL looked to the emergence of vocational education as an opportunity to insert the values of the women's labor movement into the public school curriculum. Reformers with roots in the settlement house and women's club 
movements argued that vocational education could foster healthier homes in immigrant communities if girls also learned to cook and clean. Women's groups like the Chicago WTUL and the CWC failed to implement many of these educational goals. Yet their commitment to creating new vocational programs for female students demonstrates a shared optimism among these Chicago women that reforming public education could reshape society.

\section{Notes}

1 Agnes Nestor, Woman's Labor Leader: An Autobiography (Rockford, IL: Bellevue Books, 1954), 145.

2 U.S. Census Bureau, "Table VIII," Thirteenth Census of the United States Taken in the Year 1910, Vol. IV: Population 1910-Occupation Statistics (Washington, DC: Government Printing Office, 1914), 546. On cross-class alliances between women in Progressive Era cities, see Nancy Schrom Dye, As Equals and as Sisters: Feminism, the Labor Movement, and the Women's Trade Union League of New York (Columbia: University of Missouri Press, 1980); Robyn Muncy, Creating a Female Dominion in American Reform, 18901935 (New York: Oxford University Press, 1991); Dolores Hayden, The Grand Domestic Revolution: A History of Feminist Designs for American Homes, Neighborhoods, and Cities (Cambridge, MA: MIT Press, 1992); Maureen A. Flanagan, Seeing with Their Hearts: Chicago Women and the Vision of the Good City, 1871-1933 (Princeton, NJ: Princeton University Press, 2002), 59-72; and Sarah Deutsch, Women and the City: Gender, Space, and Power in Boston, 1870-1940 (New York: Oxford University Press, 2000).

3 On the vocational education movement, see Marvin Lazerson and W. Norton Grubb, American Education and Vocationalism: A Documentary History, 1870-1970 (New York: Teachers College Press, 1974); Harvey Kantor and David B. Tyack, eds, Work, Youth, and Schooling: Historical Perspectives on Vocationalism in American Education (Stanford, CA: Stanford University Press, 1982); Harvey Kantor, Learning to Earn: School, Work, and Vocational Reform in California, 1880-1930 (Madison: University of Wisconsin Press, 1988); John Rury, Education and Women's Work: Female Schooling and the Division of Labor in Urban America, 1870-1930 (Albany, NY: State University of New York Press, 1991); Jane Bernard Powers, The "Girl Question" in Education: Vocational Education for Young Women in the Progressive Era (London: Falmer Press, 1992); Herbert M. Kliebard, Schooled to Work: Vocationalism and the American Curriculum, 18761946 (New York: Teachers College Press, 1999); and Glenn P. Lauzon, ed., Educating a Working Society: Vocationalism in Twentieth-Century American Schools (Charlotte, NC: Information Age Publishing, 2019). On class politics and Progressive Era school reform, see Julia Wrigley, Class Politics and Public Schools: Chicago, 1900-1950 (New Brunswick, NJ: Rutgers University Press, 1982); David Hogan, Class and Reform: School and Society in Chicago, 1880-1930 (Philadelphia: University of Pennsylvania Press, 1985); and William J. Reese, Power and the Promise of School Reform: Grass Roots Movements During the Progressive Era (New York: Teachers College Press, 1986).

4 "Report of the Superintendent," Fifty-Second Annual Report of the Board of Education, 1906 (Chicago: Board of Education, 1907), 135-52, Chicago Board of Education Archives (hereafter CBEA), Chicago, IL.

5 For studies on how immigration shaped Progressive Era school reform, see Alan Wieder, Immigration, the Public School, and the 20th Century American Ethos (Lanham, MD: University Press of America, 1985); Stephen Brumberg, Going to America, Going to School: The Jewish Immigrant Public School Encounter in Turn-of-the-Century New York City (New York: Praeger, 1986); Joel Perlmann, Ethnic Differences: Schooling and Social Structure among the Irish, Italians, Jews, and Blacks in an American City, 1880-1935 (Cambridge: Cambridge University Press, 1988); Paula Fass, Outside In: Minorities and the Transformation of American Education (New York: Oxford University Press, 1989); Stephanie Nicole Robinson, History of Immigrant Female Students in Chicago Public Schools, 1900-1950 (New York: Peter Lang, 2004); and Jeffrey E. Mirel, Patriotic Pluralism: Americanization Education and European Immigrants (Cambridge, MA: Harvard University Press, 2010).

6 Jane Addams, "Address," National Society for the Promotion of Industrial Education, Bulletin No. 1: Proceedings of the Organization Meetings (New York: Teachers College Press, 1907), 39, 43.

7 Organizations represented on the NSPIE included the National Association of Manufacturers, the Progressive (Bull Moose) Party, and the U.S. Chamber of Commerce. Today, the organization is called the Association for Career and Technical Education. See Robert Ripley Clough, "The National Society for the 
Promotion of Industrial Education: Case Study of a Reform Organization, 1906-1917" (master's thesis, University of Wisconsin, 1957); and Deberae Culpepper-Ofori, "The Development of Tracking and its Historical Impact on Minority Students" (PhD diss., Walden University, 2012), 83.

8 "Must Train for Industrial Race; United States Will Lose to Germany if Its Boys Are Not Better Taught," Chicago Daily Tribune (hereafter Chicago Tribune), Jan. 22, 1908, 16; "Getting Data for Trade Schools," Chicago Tribune, Dec. 10, 1907, 8; and Theodore Roosevelt, "Industrial Education," Journal of Education 67 (Feb. 1908): 201.

9 "Choice of Work," Fifty-Second Annual Report of the Board of Education, 154, CBEA; and "Asks Fair Play in Schools: Cooley Shows Necessity of Revising Present System," Chicago Tribune, Dec. 2, 1908, 8.

10 Crane Tech was privately run by the Chicago Commercial Club from 1882 to 1903 and was originally named the English High and Manual Training School. It was incorporated into the Chicago public school system in 1903, relocated to 2245 W. Jackson Blvd., and renamed after Chicago businessmen Richard T. Crane. Lane Tech, named after the former superintendent of schools, Albert G. Lane, was located at N. Sedgwick St. and Division Ave. on the north side of Chicago until relocated further north to 2501 W. Addison St. in 1933. Both schools are still standing.

11 Edwin G. Cooley, "Manual Training and Household Arts," Fifty-Fifth Annual Report of the Board of Education, 1909 (Chicago: Board of Education, 1909), 145, CBEA.

12 The other founding members of the Women's subcommittee were Sarah Louise Arnold, Emily Greene Balch, Sophonisba Breckinridge, Susan Kingsbury, Florence Marshall, and Mary Schneck Woolman. See Florence M. Marshall, "Sub-Committee on Industrial Education for Women," National Society for the Promotion of Industrial Education, Bulletin No. 4: Industrial Training for Women (Oct. 1907), 1-59; and "Is It True That the American Home Is Rapidly Deteriorating, as Some Educators Say?," New York Times, Nov. 3 1907, SM9.

13 For histories of the WTUL, see Dye, As Equals and as Sisters; Susan Amsterdam, "The National Women's Trade Union League," Social Service Review 56:2 (1982): 259-72, esp. 261; Susan Lehrer, Origins of Protective Labor Legislation for Women, 1905-1925 (Albany, NY: State University of New York Press, 1987); Elizabeth Anne Payne, Reform, Labor, and Feminism: Margaret Dreier Robins and the Women's Trade Union League (Urbana: University of Illinois Press, 1988); and Mary Elizabeth Pidgeon, Toward Better Working Conditions for Women: Methods and Politics of the National Women's Trade Union League, Bulletin 252 (Washington, DC: Women's Bureau, U.S. Department of Labor, 1953), 38, Agnes Nestor Papers, box 1 folder 1, Chicago History Museum (hereafter CHM), Chicago, IL. Also see Felice Batlan, Women and Justice for the Poor: A History of Legal Aid, 1863-1945 (Cambridge: Cambridge University Press, 2015), 37; "Report of Committee on Education," Report of Proceedings of the Second Biennial Convention of the National Women's Trade Union League of America, Chicago, IL, Sept. 25-Oct. 1, 1909, 53-54; and Rose Schneiderman, "Fourth Biennial Outlines Educational Work: Industrial Education," Life and Labor, Aug. 1913, 236.

14 "Annual Report of the Compulsory Education Department," Forty-Seventh Annual Report of the Board of Education, 1901 (Chicago: Board of Education, 1901), 45; "Ratio of Boys," Forty-Third Annual Report of the Board of Education, 1897 (Chicago: John F. Higgins Print, 1897), 66, CBEA; "Ratio of Boys," Forty-Fourth Annual Report of the Board of Education, 1898 (Chicago: John F. Higgins Print, 1898), 82, CBEA; and Edwin G. Cooley, "Map Out New School Program," Chicago Tribune, May 22, 1902, 2. For more on the prominence of girls in Progressive Era high schools, see Perlmann, Ethnic Differences; and Karen Graves, Girls' Schooling during the Progressive Era: From Female Scholar to Domesticated Citizen (New York: Garland Publishing, 1992).

15 “Lamblike' Boys?” Chicago Tribune, May 3, 1908, 3.

16 Nestor, Woman's Labor Leader, 43, 83-84, 143; and "To Be Taught Laws-No Certificate Without Knowledge of Laws," Life and Labor, Jan. 1914, 26. For more on Nestor's philosophy of vocational education, see Agnes Nestor, "Statement of Mr. Charles H. Verrill, Chief Editor of the Bureau of Labor Statistics," Report of the Commission on Vocational Aid to Vocational Education, Vol. 2: Hearings Before Commission (Washington, DC: Government Printing Office, 1914), 108; and letter from Cleo Murtland to Nestor, Feb. 18, 1914, General Correspondence, box 1, folder 7, Agnes Nestor Papers, CHM.

17 Margaret Dreier Robins, "Industrial Education for Women," National Society for the Promotion of Industrial Education, Bulletin No. 10: Proceedings, Third Annual Meeting, Milwaukee, Wis. (New York: NSPIE, 1910), 81; and Schneiderman, "Fourth Biennial Outlines Educational Work," 236-37.

18 Henry S. Pritchett, "The Aims of the National Society for the Promotion of Industrial Education," National Society for the Promotion of Industrial Education, Bulletin No. 7 (New York: NSPIE, 1908), 8. 
19 Richard T. Crane, owner of a Chicago brass company, paid to install vocational equipment in several schoolhouses and even covered the salaries of early vocational teachers. Similar expenses were paid by members of the wealthy McCormick family. See "Big Offer to Schools," Chicago Tribune, May 23, 1905, 7; and "How Educational Problems Have Been Solved in Chicago Schools," Chicago Tribune, Sept. 1, 1912, G2. For more on labor hostility toward vocational programs in Chicago, see Wrigley, Class Politics and Public Schools, $48-90$.

20 See Flanagan, Seeing with Their Hearts, 59-72; "Women on the School Board," Chicago Tribune, May 29, 1887, 2; and "The Board of Education: An Argument in Favor of Appointing Women to That Body," Chicago Tribune, May 6, 1888, 30. Also see Lana Ruegamer, “The Paradise of Exceptional Women': Chicago Women Reformers, 1863-1893” (PhD diss., Indiana University, 1982), 167; and Kate Rousmaniere, Citizen Teacher: The Life and Leadership of Margaret Haley (Albany, NY: State University of New York Press, 2005). 21 "To Teach Girls Trades: Chicago to Establish Technical High School Like Those for Boys," New York Times, 1908, 1; "Ask Girls' Rights in Trade Courses," Chicago Tribune, Jan. 10, 1909, 3; "University Girl Upholds Toilers," Chicago Tribune, Oct. 7, 1906, 5. On the CWC, see Ruegamer, "Paradise of Exceptional Women"; and Flanagan, Seeing with Their Hearts.

22 The trade schools in Boston and New York were founded by women affiliated with the Boston-based Women's Educational and Industrial Union (WEIU). See Chas. F. Pidgin, Massachusetts Bureau of Statistics of Labor, Industrial Education of Working Girls (Boston: Wright and Potter State Printers, 1905), 35-37, Newberry Library, Chicago, IL; Mary Schenck Woolman, The Making of a Trade School (Boston: Whitcomb and Barrows, 1910), 12-13; Muncy, Creating a Female Dominion in American Reform; and Batlan, Women and Justice for the Poor, 37.

23 Lynn Y. Weiner, From Working Girl to Working Mother: The Female Labor Force in the United States, 1820-1980 (Chapel Hill: University of North Carolina Press, 1985), 6; Florence M. Marshall, “The Industrial Training of Women," Annals of American Academy of Political and Social Science 33 (Jan. 1909): 124-26; Florence M. Marshall, "What the Value of the Years from Fourteen to Sixteen Might Be to Girls," Report of the Massachusetts Commission on Industrial Education (New York: Teachers College Press, April 1906), 74-79; and Alice Kessler-Harris, Out to Work: A History of Wage-Earning Women in the United States (Oxford: Oxford University Press, 2003), 174.

24 Mary Schenck Woolman, "Trade and Vocational Education for Girls," Journal of Education 76 (Dec. 1912): 696; and Woolman, Making of a Girls Trade School: Being the Organization, Work, Problems, and Equipment of the Manhattan Trade School for Girls (New York: Columbia University Teachers' College, 1909), 14. On the early history of the home economics movement, see Sarah Stage and Virginia B. Vincenti, eds., Rethinking Home Economics: Women and the History of a Profession (Ithaca, NY: Cornell University Press, 1997); Hayden, Grand Domestic Revolution; Nancy Tomes, The Gospel of Germs: Men, Women, and the Microbe in American Life (Cambridge, MA: Harvard University Press, 1998); and Daniel Eli Burnstein, Next to Godliness: Confronting Dirt and Despair in Progressive Era New York City (Urbana: University of Illinois Press, 2006).

25 Sophonisba Breckinridge, quoted in "University Girl Upholds Toilers," Chicago Tribune, Oct. 7, 1906, 5. See also Hayden, Grand Domestic Revolution; Flanagan, Seeing with Their Hearts; and Marta Gutman, A City for Children: Women, Architecture, and the Charitable Landscapes of Oakland, 1850-1950 (Chicago: University of Chicago Press, 2014).

26 Leonora O'Reilly, "Statement of Leonora O'Reilly, National Women's Trade Union League," Report of the Commission on Vocational Aid to Vocational Education, Vol. 2: Hearings Before Commission (Washington, DC: Government Printing Office, 1914), 195.

27 Robins, "Industrial Education for Women," 78.

28 Nestor, Woman's Labor Leader, 151-52. This quote refers to a 1914 compromise struck between Nestor, Florence Marshall, and various state senators on the Commission on Vocational Aid to Vocational Education over the place of home economics in girls' vocational education. See "University Girl Upholds Toilers," Chicago Tribune, Oct. 7, 1906, 5.

29 "All Girls to Sew in School: Supt. Young Plans Extension of Cooking Courses Also," Chicago Tribune, Oct. 2, 1909, 3; and "Urges Schooling for Girl Workers: Mrs. Young Says Boys Have Advantage in Technical High and Other Courses," Chicago Tribune, Sept. 28, 1909, 22. On the educational career of Ella Flagg Young, see John T. McManis, Ella Flagg Young and a Half-Century of the Chicago Public Schools (Chicago: A. C. McClurg and Co., 1916); Connie Goddard, “Ella Flagg Young's Intellectual Legacy: Theory and Practice in Chicago's Schools, 1862-1917" (PhD diss., University of Illinois Chicago, 2005); Jackie M. Blout, "Ella Flagg Young and 
the Gender Politics of Democracy and Education," Journal of the Gilded Age and Progressive Era 16 (Oct. 2017): 409-23; and Jackie M. Blout, "Individuality, Freedom, and Community: Ella Flagg Young's Quest for Teacher Empowerment," History of Education Quarterly 58 (May 2018): 175-98.

30 "Urges Schooling for Girl Workers," Chicago Tribune, Sept. 28, 1909, 22; Ella Flagg Young, "Superintendent's Report," Fifty-Ninth Annual Report of the Board of Education, 1913 (Chicago: Board of Education, 1913), 116, CBEA; and Ella Flagg Young, Ethics in the School (Chicago: University of Chicago Press, 1902), $24,28$.

31 "No Sex in School or Pupils' Minds: New Local Coeducational Argument Advanced by Mrs. Ella Flagg Young-Answers Jane Addams," Chicago Tribune, Oct. 8, 1908, 6.

32 "No Sex in School," 6.

33 Young also created a four-year manual training program for boys and a four-year household arts program for girls intended to prepare students to teach vocational subjects in Chicago public high schools. See "Give Diploma in Two Years: Authorities Arrange Special High School Course," Chicago Tribune, June 21, 1910, 1; "Two Year High School Course," Chicago Tribune, Jan. 3, 1911, 10; and "Table VIII-IX: Membership of High School Classes," Fifty-Ninth Annual Report of the Board of Education Annual Report, 319-21, CBEA.

34 "Training for Motherhood," Fifty-Eighth Annual Report of the Board of Education, 1912 (Chicago: Board of Education, 1912), 16, CBEA.

35 "What's to Be Done with the $\$ 50,000$ ?" Chicago Tribune, Jan. 19, 1911, 3; and Chicago Woman's Club, Thirty-Second Annual Announcement of the Chicago Woman's Club, 1908-1909 (Chicago: Libby and Sherwood, 1909), 49. On women's groups involvement with the 1910-11 garment strikes, see "Strikers Parade; More Aid Given," Chicago Tribune, Nov. 14, 1910, 4; and Katharine Coman, "Chicago at the Front," Life and Labor, Jan. 1911, 15. Also see Mari Jo Buhle, "Socialist Women and the 'Girl Strikers,' Chicago, 1910," Signs: Journal of Women and Culture in Society 1 (Summer 1976): 1039-51; Flanagan, Seeing with Their Hearts, 112-13; and Susan Roth Breitzer, "Uneasy Alliances: Hull House, the Garment Workers Strikes, and the Jews of Chicago," Indiana Magazine of History, Mar. 2010, 40-70.

36 Ella Flagg Young, "Technical Training for Girls," Fifty-Seventh Annual Report of the Board of Education, 1911 (Chicago: Board of Education, 1911), 92, CBEA; and "Chicago to Teach Trade for Girls Beginning in June," Chicago Tribune, Apr. 28, 1911, 1. Lucy Flower Technical High School for Girls operated out of a small schoolhouse at 26th St. and Wabash Ave. until 1926, when it was relocated to a new facility at 3545 W. Fulton Blvd. in the Garfield Park neighborhood. The school went coed in 1978, which it remained until its official closing in 2004. The building is now home to Al Raby High School and was added to the National Register of Historic Places in 2017. See Ruby Oram, "The Lucy Flower Technical High School for Girls, Chicago, IL," (Property SG100000960), National Register of Historic Places Nomination Form, June 1, 2017.

37 Ella Flagg Young, "Lucy L. Flower Technical High School," Fifty-Ninth Annual Report of the Board of Education, 266-67, CBEA; and Dora Wells, "The Lucy Flower Technical High School," The School Review 22 (Nov. 1914): 613, https://www.jstor.org/stable/1077002.

38 "Chicago's Vocational Schools," The Carpenter, Jan. 1913, 21-22; "The Apprentice Schools," Fifty-Ninth Annual Report of the Board of Education, 252-53, CBEA; "Report of the Trade Schools Committee," Apr. 1917, 1, Club Minutes, box 25, Chicago Woman's Club Records, CHM; "Report of the Trade Schools Committee," 1917, 3, Club Minutes, box 25, Chicago Woman's Club Records, CHM; and "Plan For Girls' School: Committee Head Would Use Money for Trade Institution," New York Times, Mar. 10, 1914, 10.

39 "Fears Craze for Teaching Crafts: Mrs. Ella Flagg Young Sees Peril in Turning Schools into Mere Workshops," Chicago Tribune, Dec. 4, 1912, 2; "Miss Dora Wells Selected as Girls' Trade School Head," Chicago Tribune, May 12, 1911, 7; and "Wells, "Lucy Flower Technical High School," 611-15.

40 Dora Wells, "A School Built Around the Girl," Journal of Education 16 (Nov. 1931): 374; and Wells, "Lucy Flower Technical High School," 615.

41 See Young, "Lucy L. Flower Technical High School," 268, CBEA.

42 Henriette Greenebaum Frank and Amalie Hofer Jerome, eds., Annals of the Chicago Woman's Club for the First Forty Years of Its Organization, 1876-1916 (Chicago: Chicago Woman's Club, 1916), 305-6; Pidgeon, Toward Better Working Conditions for Women, 36; "Common Welfare," The Survey 34 (June 1915): 263; and Karen Bastorello, A Power Among Them: Bessie Abramowitz Hillman and the Making of the Amalgamated Clothing Workers of America (Urbana: University of Illinois Press, 2008), 52.

43 See Sophia A. Theilgaard, "The Lucy Flower Technical High School for Girls" (unpublished diss., 1938), box 1, folder "Lucy Flower," Nancy Green Papers, CHM; and Jeanne Michael, self-completed survey on Flower Tech, n.d., box 1, folder "Interviews 1917-1939 White," Nancy Green Papers, CHM. 
44 Nell Mills, interviewed by Nancy Green, May 9, 1984, box 1, folder "Interviews 1917-1939 White," Nancy Green Papers, CHM; and Willetta Greer, interviewed by Nancy Green, Sept. 13, 1983, box 1, folder "Interviews 1922-1975 Black," Nancy Green Papers, CHM.

45 "Table VIII-IX: Membership of High School Classes," Fifty-Ninth Annual Report of the Board of Education, 319-21, CBEA; Helen Sayr Gray, "Domestic Science in the Schools and Colleges," North American Review 190 (1909): 205-7, https://www.jstor.org/stable/25106428; and "How Educational Problems Have Been Solved in Chicago Schools," Chicago Tribune, Sept. 1, 1912, G2.

46 Fannie Casseday Dundan, "The Commercial High School as a Public Asset," Journal of Education 74 (Sept. 1911):259; Sharon Strom, Beyond the Typewriter: Gender, Class, and the Origins of Modern Office Work (Urbana: University of Illinois Press, 1992), 297, 383; and “Table VIII-XI," Fifty-Ninth Annual Report of the Board of Education, 254-55, 153, CBEA.

47 "Table XIV-Evening Schools," "Table XVI-Nativity, Evening Schools," Sixtieth Annual Report of the Board of Education, 1914 (Chicago: Board of Education, 1914), 447-48, CBEA; and "For and by the Business Girls: Not Afraid of Hard Work," Chicago Tribune, Oct. 4, 1914, E4.

48 Ruth Schonle Cavan and Jordan True Cavan, "Education and the Business Girl," Journal of Educational Sociology 3 (Oct. 1929): 83; and Strom, Beyond the Typewriter, 297, 383.

49 David Carleton, Student's Guide to Landmark Congressional Laws on Education (Westport, CT: Greenwood Press, 2002), 76; and Lazerson and Grubb, American Education and Vocationalism. On home economics and the Smith-Hughes Act, see Kliebard, Schooled to Work, 135; Harold L. Ickes, "Vocational Education in Home Economics: Twelve Years of Home Economics Education Under the National Vocational Education Acts," Vocational Education Bulletin, No. 151: Home Economics Series, No. 12 (Washington, DC: United State Government Printing Office, June 1930), 153; and Elizabeth Randolph, "A Brief History of the Teaching of Home Economics in the Public Schools" (master's thesis, Butler University, 1942), 109.

50 Louise Overall, n.d., box 1, folder "Interviews 1922-1975 Black," Nancy Green Papers, CHM; Celestine Ellis Jeffries, Sept. 14, 1983, box 1, folder "Interviews 1922-1975 Black," Nancy Green Papers, CHM.

Ruby Oram, PhD, is an assistant professor of practice in the History Department at Texas State University. Her research focuses on the intersections of women's and gender history, labor history, urban history, and the history of education in Progressive Era America. Her book project in progress, tentatively titled Useful for Life, explores how women's groups reformed public education and policy through competing efforts to educate girls for work. She is also a public historian currently working to place a group of vocational schoolhouses in Chicago on the National Register of Historic Places. Her website is www.rubyoram.com.

Cite this article: Ruby Oram (2021) "A Superior Kind of Working Woman": The Contested Meaning of Vocational Education for Girls in Progressive Era Chicago. The Journal of the Gilded Age and Progressive Era 20, 392-410. https://doi.org/10.1017/S153778142100013X 